University of Nebraska - Lincoln

DigitalCommons@University of Nebraska - Lincoln

\title{
Barcoding bushmeat: molecular identification of Central African and South American harvested vertebrates
}

\author{
Mitchell J. Eaton \\ University of Colorado, Boulder \& U.S. Geological Survey, meaton@usgs.gov \\ Greta J. Meyers \\ Barnard College \\ Sergios-Orestis Kolokotronis \\ American Museum of Natural History \\ Matthew S. Leslie \\ American Museum of Natural History \\ Andrew P. Martin \\ University of Colorado, Boulder
}

See next page for additional authors

Follow this and additional works at: https://digitalcommons.unl.edu/usgsstaffpub

Part of the Geology Commons, Oceanography and Atmospheric Sciences and Meteorology Commons, Other Earth Sciences Commons, and the Other Environmental Sciences Commons

Eaton, Mitchell J.; Meyers, Greta J.; Kolokotronis, Sergios-Orestis; Leslie, Matthew S.; Martin, Andrew P.; and Amato, George, "Barcoding bushmeat: molecular identification of Central African and South American harvested vertebrates" (2010). USGS Staff -- Published Research. 1127.

https://digitalcommons.unl.edu/usgsstaffpub/1127

This Article is brought to you for free and open access by the US Geological Survey at DigitalCommons@University of Nebraska - Lincoln. It has been accepted for inclusion in USGS Staff -- Published Research by an authorized administrator of DigitalCommons@University of Nebraska - Lincoln. 
Authors

Mitchell J. Eaton, Greta J. Meyers, Sergios-Orestis Kolokotronis, Matthew S. Leslie, Andrew P. Martin, and George Amato 


\title{
Barcoding bushmeat: molecular identification of Central African and South American harvested vertebrates
}

\author{
Mitchell J. Eaton · Greta L. Meyers • \\ Sergios-Orestis Kolokotronis · Matthew S. Leslie • \\ Andrew P. Martin · George Amato
}

Received: 28 February 2009/Accepted: 23 July 2009/Published online: 1 September 2009

(C) Springer Science+Business Media B.V. 2009

\begin{abstract}
The creation and use of a globally available database of DNA sequences from a standardized gene region has been proposed as a tool for species identification, assessing genetic diversity and monitoring the legal and illegal trade in wildlife species. Here, we contribute to the Barcode of Life Data System and test whether a short region of the mitochondrial cytochrome $c$ oxidase subunit 1 (COXI) gene would reliably distinguish among a suite of commonly hunted African and South American mammal and reptile species. We used universal primers to generate reference barcode sequences of 645 bp for 23 species from five vertebrate families (Crocodilidae, Alligatoridae, Bovidae, Suidae and Cercopithecidae). Primer cocktails yielded high quality barcode sequences for 179 out of 204 samples $(87.7 \%)$ from all species included in the study. For most taxa, we sequenced multiple individuals to estimate intraspecific
\end{abstract}

Electronic supplementary material The online version of this article (doi:10.1007/s10592-009-9967-0) contains supplementary material, which is available to authorized users.

M. J. Eaton · A. P. Martin

Department of Ecology and Evolutionary Biology,

N122 Ramaley, University of Colorado, Boulder, CO 80309, USA

G. L. Meyers

Department of Environmental Science, Barnard College, 3009

Broadway, 404 Altschul Hall, New York, NY 10027, USA

S.-O. Kolokotronis - M. S. Leslie - G. Amato

Sackler Institute for Comparative Genomics, American Museum of Natural History, Central Park West at 79th Street, New York, NY 10024, USA

M. J. Eaton $(\bowtie)$

Patuxent Wildlife Research Center, US Geological Survey,

12100 Beech Forest Road, Laurel, MD 20708-4017, USA

e-mail: meaton@usgs.gov; eaton.mitch@gmail.com sequence variability and document fixed diagnostic characters for species identification. Polymorphism in the COXI fragment was generally low (mean $=0.24 \%$ ), while differences between congeneric species averaged 9.77\%. Both fixed character differences and tree-based maximum likelihood distance methods unambiguously identified unknown and misidentified samples with a high degree of certainty. Barcode sequences also differentiated among newly identified lineages of African crocodiles and identified unusually high levels of genetic diversity in one species of African duiker. DNA barcoding offers promise as an effective tool for monitoring poaching and commercial trade in endangered species, especially when investigating semi-processed or morphologically indistinguishable wildlife products. We discuss additional benefits of barcoding to ecology and conservation.

Keywords Barcode of life - Caiman - Crocodiles . Cytochrome $c$ oxidase subunit $1(C O X 1) \cdot$ Hunting . Molecular forensics · Primates · Wildlife monitoring · Maximum likelihood phylogeny $\cdot$ Ungulates

\section{Introduction}

The hunting of tropical wildlife has historically been conducted for subsistence consumption and for local trade. But current trends in wildlife harvest from across the globe suggest that the volume of extraction of wild game, or "bushmeat", has increased considerably, and many species are in sharp decline due to over exploitation (Albrechtsen et al. 2007; Bennett et al. 2007; Milner-Gulland et al. 2003; Redford 1992). Former locally-based subsistence economies have become global, and bushmeat is now a significant export product traded at regional and international 
scales. Of equal importance to the deleterious impacts on wild populations and ecosystems promoted by unregulated harvest are the potential human and agricultural heath impacts stemming from the increased potential for zoonotic disease transfer (Chomel et al. 2007; Milius 2005).

Considering the international trade in bushmeat and fisheries, estimates of its worth are in excess of US\$60 billion per year, with wildlife and wildlife products contributing US\$5-15 billion (Baker 2008). A significant portion of this trade is illegal (US\$5-8 billion, in Baker 2008), involving species that are protected by national laws and international conventions governing the use of wildlife and wildlife products. Given the illicit nature of the trade, it is difficult to accurately assess and monitor the volumes and species involved (Chomel et al. 2007; Milius 2005) and thus fully understand existing and potential impacts on economies, wildlife populations and health.

Existing legislation and treaties governing the trade in wildlife, such as the Convention on the International Trade of Endangered Species (CITES) and the United States Endangered Species Act (ESA), are based on the recognition of distinct population or taxonomic units. At a minimum, enforcement of regulations depends upon an ability to identify suspected illegal products at the species level. Accurate identification is often impaired due to the types of products involved, which are typically processed and difficult to identify using morphological techniques. To improve our ability to detect, monitor and control the trade in wildlife and wildlife products, more accurate and efficient methods of species identification are required. Identification of fish and wildlife species targeted for commercial trade is considered among the most useful applications of molecular ecology (Baker 2008).

The ability to identify wildlife products, whether as processed meat, skins or whole animals, is being formalized by the development of DNA sequence databases using a standardized gene fragment (Ratnasingham and Hebert 2007; Ross et al. 2003). A database of single-gene "barcodes" has been proposed to classify the complete diversity of life (Hebert et al. 2003a; Ratnasingham and Hebert 2007) and proponents argue that such a tool could variously be employed for defining taxonomic units for conservation (Neigel et al. 2007; but see Rubinoff 2006), biological inventory (Janzen et al. 2005) and species discovery (Bickford et al. 2007; Hebert et al. 2004; Kaila and Stahls 2006; Witt et al. 2006). The $5^{\prime}$ Folmer region of the mitochondrial (mtDNA) cytochrome $c$ oxidase I (COXI) gene has been recommend as a standard for DNA barcoding (Folmer et al. 1994; Hebert et al. 2003a, b; Ivanova et al. 2007). Although there has been considerable criticism of the philosophical and practical underpinnings of DNA barcoding (DeSalle 2006; Fitzhugh 2006; Rubinoff 2006; Rubinoff et al. 2006;
Song et al. 2008), its application for species identification has largely been uncontested (e.g. Rubinoff et al. 2006).

The use of sequence data for investigations of endangered species collected in commercial markets is widely reported. While the COX1 region has not been used as a standard metric, these studies have employed mitochondrial markers to identify samples to the species level. Yan et al. (2005) used the cytochrome $b(C Y T B)$ gene to identify Chinese alligators (Alligator sinensis) from fresh and partially cooked meat found in Chinese markets. Baker and colleagues used mtDNA sequences and microsatellites to identify endangered whale species sampled from markets in Korea and Japan (Baker et al. 1996, 2002). Using diagnostic characters in $C Y T B$, Birstein et al. (1998) identified three species of caviar-producing sturgeon and discovered that nearly a quarter of commercially available caviar lots sold in New York City were mislabeled. Marko et al. (2004) also used CYTB sequences to determine that $77 \%$ of fish sold in the US labeled as red snapper were actually other species. Martin (1991) and Moura et al. (2008) used mtDNA sequences, including $C O X 1$, to identify commercially fished shark species when morphological characters (e.g. fins, heads) were equivocal in discerning among and within genera. The identification of endangered wildlife products in each of these cases would not have been possible without molecular methods because vendors had a vested interest in concealing the identity of the species being sold.

Ours is the first study to examine the utility of universal COX1 primers as a standard metric to identify multiple species for monitoring the global trade in wildlife, with particular emphasis on species commonly traded in bushmeat markets. Our study includes species from five taxonomic families: bovids (duikers and spiral-horned antelope; genera: Cephalophus, Tragelaphus), suids (red river hog; genus: Potamochoerus), cercopithecoid primates (old world monkeys and mangabeys; genera: Cercopithecus, Lophocebus), alligators (genera: Caiman, Melanosuchus, Paleosuchus) and crocodiles (genera: Crocodylus, Osteolaemus, Mecistops) (Table 1). We obtained samples either from museum collections or from in situ captures. We use fixed diagnostic characters to compare interspecific and intergeneric levels of variation and bootstrap node support from a maximum likelihood (ML) tree-based approach to assess the monophyly of closely related species. Diagnostic characters and phylogenetic support were also used to assign a small number of unidentified samples to species and to examine the museum collection and field specimens for possible errors in species identification or labeling. The poor quality of some tissue used in this study reflects the suboptimal conditions encountered when working with material sampled from bushmeat markets, processed wildlife products, or reference museum samples 


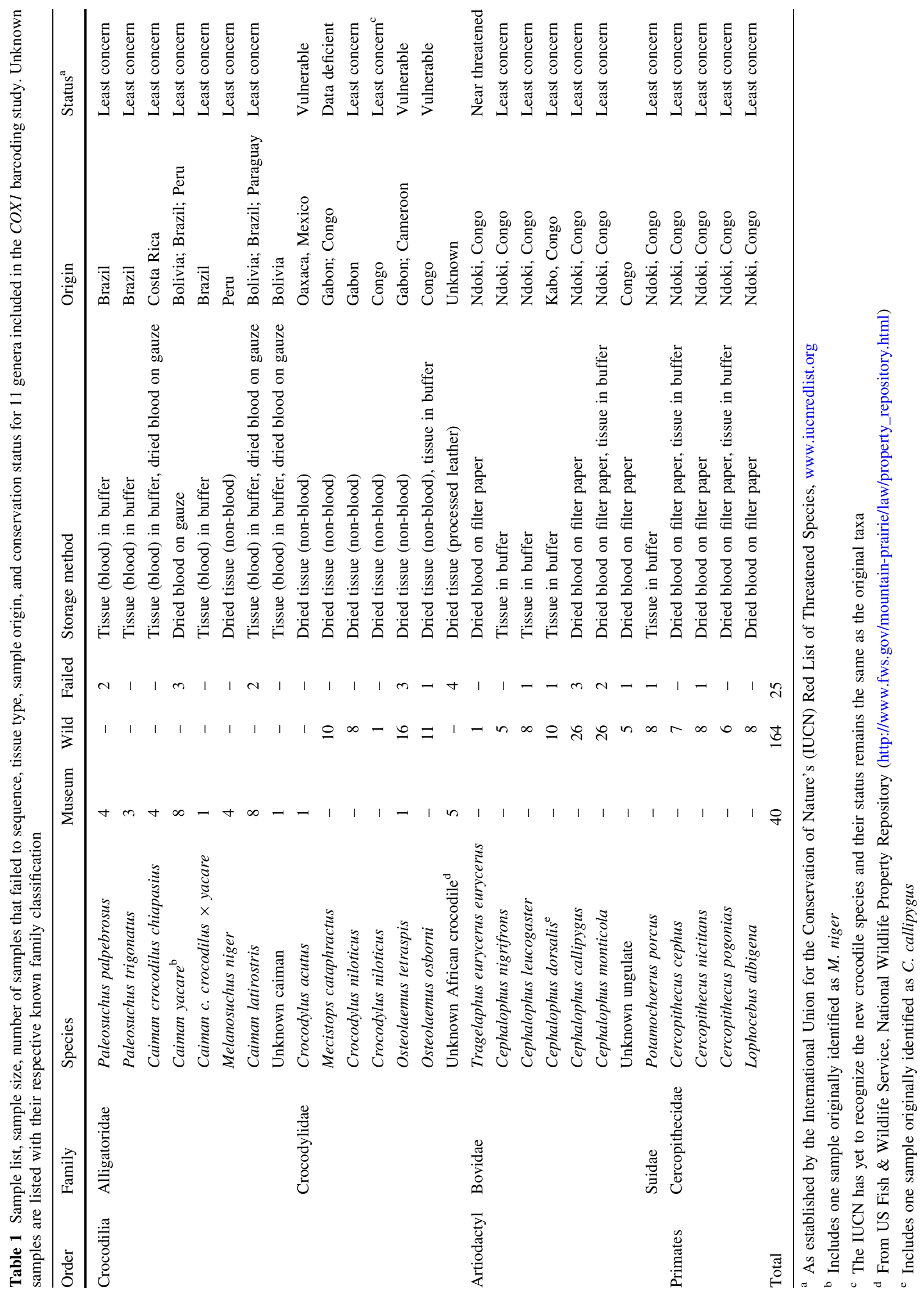


and, therefore, provides a robust evaluation of the utility of DNA barcoding for wildlife monitoring and investigations.

\section{Materials and methods}

Species identification and sample collection

Specimens used in this study were identified and collected under four different scenarios. The first involved harvested mammals surveyed during a prior study of bushmeat hunting in the Republic of Congo (Table 1; Eaton 2002). Species identifications were made by MJE and trained field assistants using African mammal guides (Estes 1991; Kingdon 1997) in conjunction with the knowledge of local hunters. Voucher photographs were taken of all species and later confirmed using Nowak (1999). All samples, with the exception of five unidentified ungulates, were collected from freshly killed, whole animals in which species identification was unambiguous. The five unidentified samples were collected from partially butchered animals that could only be confirmed as belonging to ungulates based on hair pattern and coloration. Samples of Osborn's dwarf crocodiles (Osteolaemus osborni) and a single Nile crocodile (Crocodylus niloticus) were collected from intact, hunted animals during a subsequent study in the Republic of Congo (Eaton et al. 2009; Thorbjarnarson and Eaton 2004). The second sample collection scenario consisted of capture and identification of live African crocodiles for systematics and ecological research in the Republics of Congo and Gabon (Eaton 2006; Eaton and Barr 2005; Eaton et al. 2009; Thorbjarnarson and Eaton 2004). Although there have been recent revisions to the taxonomy of all African crocodiles (Eaton et al. 2009; Hekkala 2004; McAliley et al. 2006; Schmitz et al. 2003), identification to genus (and in most cases to species) was unambiguous. The third source of samples was voucher crocodilian specimens obtained from museum collections. These included dried blood and tissue from six species of South American caiman, the American crocodile (Crocodylus acutus) and the Central African dwarf crocodile (Osteolaemus tetraspis) provided by the Yale Peabody Museum (YPM) and the American Museum of Natural History (AMNH; see Table 2 for details and accession numbers). One sample was identified only as 'caiman' (YPM 15394) and analyzed as an unknown species. The final source of samples used in this study was wildlife products confiscated by the US Fish and Wildlife Service as illegal imports and donated to this project as research material. Aside from originating in Africa, the specimens (five crocodile skin handbags) contained no additional information on location or species. These unidentified samples were included in the study to test the ability of standard barcode primers to amplify highly degraded material. Field-collected tissue samples were stored in $10 \%$ buffered EDTA-DMSO and kept at room temperature for up to several months before being stored at $-20^{\circ} \mathrm{C}$; blood samples were applied directly to Whatman filter paper (Florham Park, NJ), then dried and stored at room temperature for nearly 10 years.

DNA extraction, amplification and sequencing

Samples included in the study had been stored as preserved fresh tissue, dried tissue, blood dried in buffer, blood dried on filter paper, and processed skin products. DNA was extracted from tissue and blood using DNEasy kits (Qiagen) in a pre-PCR laboratory to prevent contamination. Extractions followed the manufacturer's protocol for buffered animal tissues but were modified slightly for extraction of DNA from dried blood or older tissue to ensure maximum yield from low-quality samples. Modifications included incubating the lysed tissue at $65^{\circ} \mathrm{C}$ for 15 min after adding AL buffer and incubating again at $4^{\circ} \mathrm{C}$ for $1 \mathrm{~h}$ after adding ethanol. To maximize final yield of genomic DNA, $75 \mu$ l of $\mathrm{AE}$ buffer, preheated to $70^{\circ} \mathrm{C}$, was added and left to incubate for $45 \mathrm{~min}$ before centrifuging and collecting flow-through. Because the processed crocodile leather products were the most difficult to extract, we assessed their DNA yield using a NanoDrop ND-1000 spectrophotometer (Thermo Fisher Scientific).

Sequence data were generated using one of three universal COX1 primer “cocktails" (Table 3; Ivanova et al. 2007). Primer selection for each taxon was made through polymerase chain reaction (PCR) optimization of cocktails 'COI-1,' 'COI-2' and 'COI-3' and one individual primer (VF1d_t1/VR1d_t1) using representative samples from each genus of artiodactyl, primate and crocodilian included in the study, including positive control samples previously sequenced at other gene regions. Table 3 summarizes the taxon-specific primer combinations. PCR was performed in Mastercycler EP gradient $S$ thermocyclers (Eppendorf) in a $25 \mu \mathrm{l}$ reaction volume containing $1.0 \mu \mathrm{l}$ genomic DNA ( $25 \mathrm{ng} / \mu \mathrm{l}$ ), $1 \times$ PCR Buffer (Fisher Scientific), $0.24 \mu \mathrm{M}$ dNTPs, 15 ng BSA, 1 U Taq polymerase (Fisher Scientific), and $0.4 \mu \mathrm{M}$ of each forward and reverse primer or primer cocktail (Integrated DNA Technologies). Failed amplifications were repeated under the same conditions with $2 \mu \mathrm{l}$ of genomic DNA. Generally, the optimized PCR thermal cycling profile was a step-up protocol of $94^{\circ} \mathrm{C}$ for $3 \mathrm{~min}, 5$ cycles of $94^{\circ} \mathrm{C}$ for $30 \mathrm{~s}, 51.1^{\circ} \mathrm{C}$ for $40 \mathrm{~s}$ and $72^{\circ} \mathrm{C}$ for $1 \mathrm{~min}$, followed by 30 cycles of $94^{\circ} \mathrm{C}$ for $30 \mathrm{~s}, 56.9^{\circ} \mathrm{C}$ for $40 \mathrm{~s}$ and $72^{\circ} \mathrm{C}$ for $1 \mathrm{~min}$, with a final extension at $72^{\circ} \mathrm{C}$ for $10 \mathrm{~min}$. The COI- 1 primer cocktail required a different annealing temperature, $\left(54.2^{\circ} \mathrm{C}\right)$ for the first 5 cycles. PCR products were visualized by agarose gel electrophoresis, and the cocktail or primer pair yielding the brightest, thinnest band 
Table 2 Accession and locality information for museum and US Fish and Wildlife crocodilian specimens sequenced for COX1 barcoding

\begin{tabular}{|c|c|c|c|c|c|c|}
\hline Study ID & $\begin{array}{l}\text { Institution } \\
\text { accession } \#^{\mathrm{a}}\end{array}$ & Species & Country & Locality & $\begin{array}{l}\text { Collection } \\
\text { year }\end{array}$ & Sex \\
\hline Caiman1 & YPM 15394 & Caiman & Bolivia & Tarija Dept & 1986 & \\
\hline C. c. chiapasius 3 & YPM 15709 & Caiman crocodilus chiapasius & Costa Rica & Puntarenas Province & 1993 & M \\
\hline C. c. chiapasius 4 & YPM 15713 & Caiman crocodilus chiapasius & Costa Rica & Puntarenas Province & 1993 & M \\
\hline C. c. chiapasius 16 & YPM 15741 & Caiman crocodilus chiapasius & Costa Rica & Alajuela Province & 1993 & \\
\hline C. c. chiapasius 17 & YPM 15743 & Caiman crocodilus chiapasius & Costa Rica & Alajuela Province & 1993 & \\
\hline C. yacare7 & YPM 15402 & Caiman crocodilus yacare & Bolivia & SantaCruz Dept & 1989 & \\
\hline C. yacare8 & YPM 15401 & Caiman crocodilus yacare & Bolivia & El Beni Dept & 1986 & \\
\hline C. yacare 15 & YPM 15683 & Caiman crocodilus yacare & Brazil & Mato Grosso State & 1987 & \\
\hline C. yacare 32 & YPM 15570 & Caiman crocodilus yacare & Brazil & Mato Grosso Estate & 1987 & $\mathrm{~F}$ \\
\hline C. yacare 33 & YPM 15410 & Caiman crocodilus yacare & Bolivia & Pando Dept & 1986 & \\
\hline C. yacare 34 & YPM 15775 & Caiman crocodilus yacare & Paraguay & Misiones Dept & 1986-1987 & \\
\hline C. yacare 35 & YPM 15669 & Caiman crocodilus yacare & Brazil & Mato Grosso State & 1986-1987 & \\
\hline $\begin{array}{l}\text { C.c. crocodilus } \\
\times \text { yacare } 2\end{array}$ & YPM 15547 & C.c.crocodilus $\times$ yacare & Brazil & Amazonas State & 1987 & $\mathrm{~F}$ \\
\hline C. latirostris5 & YPM 15754 & Caiman latirostris & Paraguay & Presidente Hayes Dept & 1986-1987 & \\
\hline C. latirostris6 & YPM 15755 & Caiman latirostris & Paraguay & Neembucu Dept & $1986-1987$ & \\
\hline C. latirostris 18 & YPM 15392 & Caiman latirostris & Bolivia & Tarija Dept & 1986 & \\
\hline C. latirostris 19 & YPM 15554 & Caiman latirostris $^{\mathrm{b}}$ & Brazil & Espirito Santo State & 1989 & \\
\hline C. latirostris 20 & YPM 15551 & Caiman latirostris $^{\mathrm{b}}$ & Brazil & Espirito Santo State & 1989 & \\
\hline C. latirostris 21 & YPM 15548 & Caiman latirostris & Brazil & Mato Grosso du Sol & 1987 & M \\
\hline C. latirostris 22 & YPM 15754 & Caiman latirostris & Paraguay & Presidente Hayes Dept & $1986-1987$ & \\
\hline C. latirostris 23 & YPM 15393 & Caiman latirostris & Bolivia & Tarija Dept & 1986 & \\
\hline M. niger9 & YPM 15833 & Melanosuchus niger & Peru & Madre de Dios Dept & 1984 & \\
\hline M. niger10 & YPM 15834 & Melanosuchus niger & Peru & Madre de Dios Dept & 1984 & \\
\hline M. niger24 & YPM 15695 & Melanosuchus niger & Peru & Madre de Dios Dept & 1987 & $\mathrm{~F}$ \\
\hline M. niger25 & YPM 15832 & Melanosuchus niger ${ }^{\mathrm{c}}$ & Peru & Madre de Dios Dept & 1984 & \\
\hline M. niger26 & YPM 15835 & Melanosuchus niger & Peru & Madre de Dios Dept & 1984 & \\
\hline P. palpebrosus 11 & YPM 15703 & Paleosuchus palpebrosus & Brazil & Mato Grosso State & 1987 & \\
\hline P. palpebrosus 12 & YPM 15702 & Paleosuchus palpebrosus ${ }^{\mathrm{b}}$ & Brazil & Rondonia State & 1987 & \\
\hline P. palpebrosus 28 & YPM 15697 & Paleosuchus palpebrosus ${ }^{\mathrm{b}}$ & Brazil & Rondonia State & 1987 & \\
\hline P. palpebrosus 29 & YPM 15704 & Paleosuchus palpebrosus & Brazil & Mato Grosso State & 1988 & \\
\hline P. trigonatus 13 & YPM 15705 & Paleosuchus trigonatus & Brazil & Rodinia State & 1987 & $\mathrm{~F}$ \\
\hline P. trigonatus 31 & YPM 15700 & Paleosuchus trigonatus & Brazil & Rodinia State & 1987 & \\
\hline P. trigonatus14 & YPM 15699 & Paleosuchus trigonatus & Brazil & Rodinia State & 1987 & \\
\hline C. acutusM7 & AMNH R100634 & Crocodylus acutus & Mexico & Oaxaca & 1967 & \\
\hline O. tetraspisM11 & AMNH R75421 & Osteolaemus tetraspis & Cameroon & Unknown & Unknown & \\
\hline 1USFWS & USFWS PB800 & African crocodile $1^{\mathrm{d}}$ & Africa & Unknown & Unknown & \\
\hline 2USFWS & USFWS C5236 & African crocodile $2^{\mathrm{b}}$ & Africa & Unknown & Unknown & \\
\hline 3USFWS & USFWS C7848 & African crocodile $3^{\mathrm{b}}$ & Africa & Unknown & Unknown & \\
\hline 4USFWS & USFWS C6688 & African crocodile $4^{\mathrm{b}}$ & Africa & Unknown & Unknown & \\
\hline 5USFWS & USFWS C3508 & African crocodile $5^{\mathrm{b}}$ & Africa & Unknown & Unknown & \\
\hline
\end{tabular}

a Yale Peabody Museum (YPM); American Museum of Natural History (AMNH); US Fish \& Wildlife Service National Wildlife Property Repository (USFWS)

${ }^{\mathrm{b}}$ Unsuccessfully sequenced

${ }^{\mathrm{c}}$ Determined to be $C$. yacare

${ }^{\mathrm{d}}$ Determined to be $C$. niloticus 
Table 3 Primers, primer cocktails and universal M13 tails used to sequence all samples included in this study. Table and primer information modified from Ivanova et al. (2007). Position of M13 tail indicated by $[M 13 F]$ or $[M 13 R]$

\begin{tabular}{|c|c|c|}
\hline Name & Ratio & Cocktail name/Primer sequence $5^{\prime}-3^{\prime}$ \\
\hline \multicolumn{3}{|c|}{$\begin{array}{l}\text { COI-1 duikers (Cephalophus spp.), red river hog (Potamochoerus porcus), gray-cheeked mangabej } \\
\text { (Lopohocebus albigena) }\end{array}$} \\
\hline $\mathrm{FF} 2 \mathrm{~d}$ & 1 & TTCTCCACCAACCACAARGAYATYGG \\
\hline FR1d & 1 & CACCTCAGGGTGTCCGAARAAYCARAA \\
\hline \multicolumn{3}{|c|}{ COI-2 guenons (Cercopithecus spp.), in bold; bongo (Tragelaphus eurycerus) } \\
\hline LepF1_t1 & 1 & {$[M 13 F]$ ATTCAACCAATCATAAAGATATTGG } \\
\hline VF1_t1 & 1 & {$[M 13 F]$ TCTCAACCAACCACAAAGACATTGG } \\
\hline VF1d_t1 & 1 & [M13F]TCTCAACCAACCACAARGAYATYGG \\
\hline VF1i_t1 & 3 & [M13F]TCTCAACCAACCAIAAIGAIATIGG \\
\hline LepRI_t1 & 1 & [M13R]TAAACTTCTGGATGTCCAAAAAATCA \\
\hline VR1d_t1 & 1 & [M13R]TAGACTTCTGGGTGGCCRAARAAYCA \\
\hline VR1_t1 & 1 & [M13R]TAGACTTCTGGGTGGCCAAAGAATCA \\
\hline VR1i_t1 & 3 & [M13R]TAGACTTCTGGGTGICCIAAIAAICA \\
\hline \multicolumn{3}{|c|}{ COI-3 (crocodilians) } \\
\hline VF2_t1 & 1 & {$[M 13 F]$ CAACCAACCACAAAGACATTGGCAC } \\
\hline FishF2_t1 & 1 & {$[M 13 F]$ CGACTAATCATAAAGATATCGGCAC } \\
\hline FishR2_t1 & 1 & [M13R]ACTTCAGGGTGACCGAAGAATCAGAA \\
\hline FR1d_t1 & 1 & [M13R]ACCTCAGGGTGTCCGAARAAYCARAA \\
\hline M13F $(-21)$ & & TGTAAAACGACGGCCAGT \\
\hline M13R (-27) & & CAGGAAACAGCTATGAC \\
\hline
\end{tabular}

was chosen for each taxon. PCR products were purified with Ampure magnetic beads (Agencourt Bioscience) on a BioMek FX robotic platform (Beckman Coulter Inc.). Primer cocktails COI-2 and COI-3 included a modified forward and reverse universal M13 tag (Ivanova et al. 2007). A single primer pair, M13(-21) and M13(-27), was used for bidirectional sequencing reactions of PCR products generated from these two cocktails using BigDye v1.1 chemistry (Applied Biosystems Inc.) on a 3730xl DNA Analyzer (Applied Biosystems, Inc.). Forward and reverse sequences were assembled and edited in Sequencher 4.6 (Gene Codes Corp.) and verified by eye. Contig sequences were aligned using ClustalW (Thompson et al. 1994) as implemented in MEGA 4.0 (Tamura et al. 2007).

\section{Sequence analysis}

Unidentified crocodilian and ungulate samples were sequenced but then set apart from the remaining data set. All sequences obtained from species identified through museum collections or by independent morphological evaluation were grouped into their respective taxa and examined for diagnostic molecular characters that could be used as identifiers in future studies. Because species misidentifications are possible in field studies, as well as in the accession of voucher museum specimens, we examined both field and museum samples for obvious errors in species designation. Samples with possible mistaken identities were compared with all other known species to determine if a match could be made based on diagnostic characters.
Because of small sample sizes for several taxa and the associated problems of overestimating diagnostic character sites (Brower 1999; Davis and Nixon 1992), we also confirmed misidentified specimens by means of their placement on phylogenetic trees. We used maximum likelihood (ML) phylogenetic inference as implemented in RAxML 7.0.4 (Stamatakis 2006) using the general time-reversible (GTR) substitution model (Lanave et al. 1984; Rodriguez et al. 1990) with rate heterogeneity parameters modeled by the Gamma $(\Gamma)$ distribution and four rate categories (Yang 1994). Node support was evaluated with 100 rapid bootstrap replicates (Stamatakis et al. 2008). Outgroups included the American alligator (Alligator mississippiensis) for both Crocodylidae and Alligatoridae, the bongo (Tragelaphus eurycerus eurycerus) for the ungulate phylogeny, and the rhesus macaque (Macaca mulatta) for primates. Resulting trees were inspected for monophyletic groupings and for phylogenetic support values of nodes subtending possibly misidentified samples. Mistakes that could unambiguously be attributed to a species based on matching of diagnostic characters and phylogenetic placement were included in their respective taxonomic group for subsequent analyses.

Sequence variability in $C O X 1$ was evaluated at three hierarchical levels: among conspecifics, among congeneric species and among genera within each of the three orders included in this study. The bongo (T. eurycerus eurycerus) and the American crocodile (Crocodylus acutus), each represented by only one sample, were excluded from these analyses. Intraspecific comparisons quantified nucleotide diversity for each species based on average nucleotide 
substitutions per site (transitions + transversions) using a Tamura-Nei model with pairwise sequence comparisons (Tamura and Nei 1993). To compare congeneric species, we identified fixed nucleotide character differences for every species pair within each represented genus and calculated species divergence using the same Tamura-Nei substitution model. This same approach was used to compare average genus-level nucleotide divergence among orders. Positions that contained a fixed character state among all individuals within a species and an alternate but fixed state at the homologous site in the second species were considered diagnostic at the species level. We used MEGA for genetic diversity and divergence calculations and for visual examination of homologous character state positions among congeneric species. We assessed species monophyly and divergence among sister taxa by observing the resulting ML trees and node support values.

Treating the unknown ungulate, caiman and crocodile samples as a test case for species identification, we compared their sequences against diagnostic characters from our set of known species and included these samples in a reanalysis of ML phylograms. Unidentified samples were assigned to described species based on three criteria. First, an unidentified sample had to be included within a monophyletic group with bootstrap support exceeding $95 \%$. Second, its sequence had to be at least $98 \%$ similar to the most common haplotype from a described taxon. Third, its inclusion into a particular monophyletic group had to preserve diagnostic character sites previously identified in that group. We considered these criteria sufficiently conservative to prevent type I errors (incorrectly attributing a sample to the wrong species).

\section{Results}

Primer selection and sequencing of degraded tissue and blood

The universal primers of Ivanova et al. (2007) reliably sequenced a $645 \mathrm{bp}$ fragment of COX1 mtDNA for all mammal and reptile species included in this study. Based on gel visualization, the COI-I cocktail worked optimally for duikers (Cephalophus spp.), the red river hog (Potamochoerus porcus) and the gray-cheeked mangabey (Lophocebus albigena). COI-2 worked best for the bongo, while a single primer pair from this cocktail [V(F,R)1d_t1] was optimal for the guenons (Cercopithecus spp.). Cocktail COI-3 worked for all species of crocodilians (Table 3).

Because monitoring of the bushmeat trade using DNA barcoding identification will often require amplification of degraded tissue samples, we evaluated the success of universal $C O X 1$ primers on samples varying widely in age and curation method. The crocodile skin products proved difficult, with widely varying but generally low average DNA concentrations $(13.5 \mathrm{ng} / \mu \mathrm{l}, \mathrm{SD}=13.9)$ and low purity (average 260:280 $\mathrm{nm}=1.46, \mathrm{SD}=0.34$ ). We were able to extract template DNA from two of the five leather products but only one of these produced a bidirectional COX1 sequence $($ DNA yield $=16.35 \mathrm{ng} / \mu \mathrm{l}$ ). We were able to obtain high-quality sequence data from a total of 179 of 204 samples tested (87.7\%; Table 1). Of 43 samples that originally failed to sequence, seven were successfully sequenced following a second round of PCR amplification and 11 others produced sequences after a re-extraction of genomic DNA. Of the 25 samples that ultimately failed to yield sequences, nine produced visible PCR bands of the approximate molecular weight of the $C O X 1$ fragment, but failed to sequence even after a second round of extraction and amplification. Final clean trace files of all sequenced samples (with the exception of six previously unidentified specimens, Table 1) were contributed to the BOLD database (Ratnasingham and Hebert 2007) at http://www. barcodinglife.org and sequences deposited on NCBI GenBank under accession numbers: GQ144467-GQ144639.

\section{Correction of misidentified specimens}

Based on diagnostic sites and branch placement on the ML tree, we discovered two discrepancies in species identification. One caiman sample ( $M$. niger25) aligned unambiguously with Caiman yacare (Fig. 1a), but was labeled as belonging to Melanosuchus niger. It is unclear whether the specimen's label was switched in the lab or the collections, misidentified in the field or incorrectly accessioned; the YPM reptile staff is investigating (G.J. Watkins-Colwell, pers. comm.). One ungulate sample collected in the field and labeled as Peter's duiker ( $C$. callipygusYF42) was identical to the most common haplotype of the bay duiker (Cephalophus dorsalis; Fig. 1b).

Intraspecific sequence variation

Within-species nucleotide diversity (average rate of nucleotide substitutions per site) in the $C O X 1$ gene ranged from 0.0 to $1.92 \%$ (Table 5). The greatest amount of variability was observed in the Nile crocodile (Crocodylus niloticus). However, recent studies of this species using several mtDNA and nuDNA markers support a species-level division between northwestern and southeastern Africa (Hekkala 2004; Schmitz et al. 2003), though the geographic extent of each clade is not yet resolved. Eight of our Nile crocodile samples were captured in Gabon and, when we analyzed this geographic group separately, exhibited $<0.01 \%$ nucleotide diversity (Table 5). 
(a)

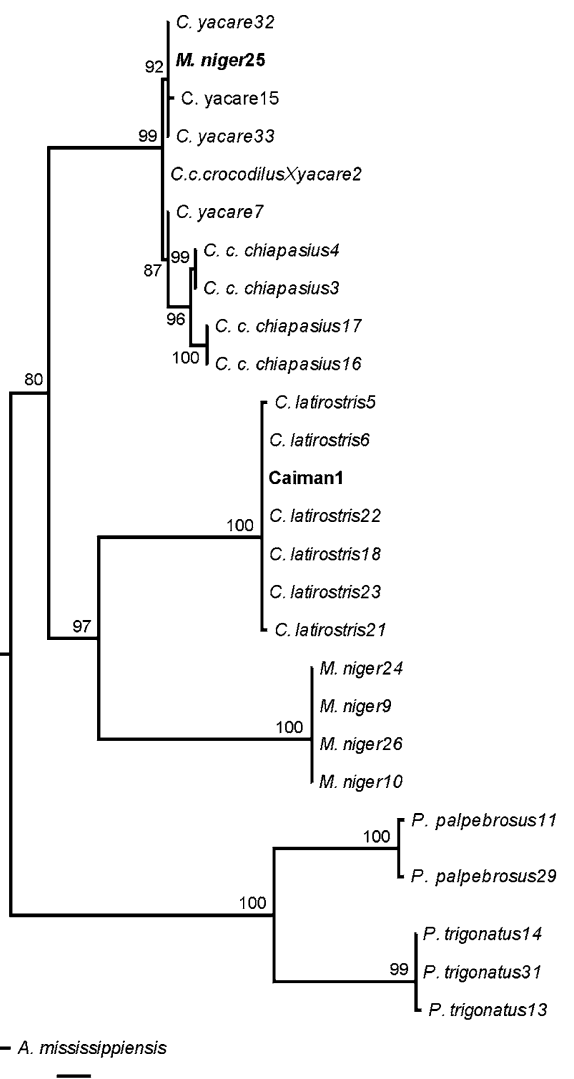

$\overline{0.01}$

(c) (b)

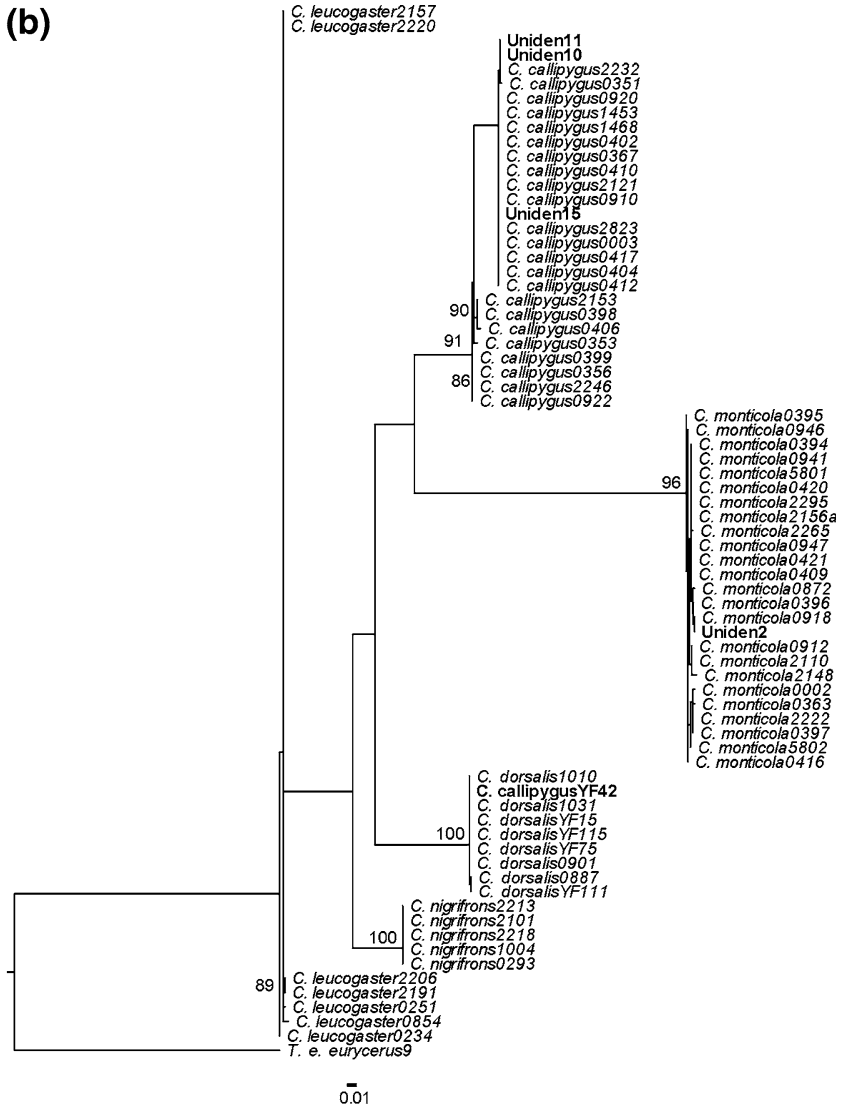

$100 \quad\left\{\begin{array}{l}\text { O. tetraspis } 102 \\ \text { O. tetraspis } 139 \\ \text { O. tetraspis } 551 \\ \text { O. tetraspis } 187 \\ \text { O. tetraspis127 } \\ \text { O. tetraspis } 101\end{array}\right.$

O. tetraspis 556
O. tetraspis 557
O. tetraspis 156
O. tetraspis 554
O. tetraspis 201
O. tetraspis 146
O. tetraspis 220
O. tetraspisM11
O. tetraspis 102
O. tetraspis 139
O. tetraspis 551
O. tetraspis 187
O. tetraspis 127
O. tetraspis 101

O. osbornig2

0. osborni93

O. osborni117

O. osborni108

100 O. osbornig5

O. osbornit46

O. osborni 115
O. osborni94

$100 \mid$ M. cataphractus $G 13$

O. osbornitog

M. cataphractus $G 9$

M. cataphractus $G 15$

M. cataphractus $G 14$

M. cataphractus G5

M. cataphractusC 4

M. cataphractusC1

96 M. cataphractus G7

M. cataphractus $C 1 M$
$M$. cataphractus $C 2 M$

M. cataphractus $C 2 M$

c. nicoticus $G 37$

c. nicoticus $G 48$

C. nicoticus $G 47$

C. nicoticus $G 46$

100 C. nicoticus G36

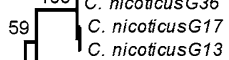

C. nicoticusG13

C. acutusM7

1USFWS

A. mississippiensis

$\overline{0} 01$ 
4 Fig. 1 Maximum likelihood phylograms for a South American caimans, b African duikers, and c African crocodiles. Unknown, blind or misidentified samples are shown in bold type. Node support values are based on filtering the best maximum likelihood tree through 100 rapid bootstrap replicate trees. Log-likelihood and alpha shape parameter values, respectively, were a $-1,949.953015$ and 0.199779 , b $-1,888.9429$ and 0.02 , and $\mathbf{c}-1,965.181261$ and 0.248764

We observed the second greatest amount of intraspecific diversity (1.18\%) in 26 specimens of Peter's duiker (Cephalophus callipygus; Table 5). A subset of eight $C$. callipygus exhibited fixed differences at 13 out of 21 variable sites found within the larger group (Table 5) and formed a paraphyletic assemblage with moderate bootstrap support $(<85 \%$, Fig. 1b). When polymorphisms were evaluated separately for the two groups, diversity was $0.41 \%$ for the eight individuals and $0.05 \%$ in the remaining 18 individuals (Table 5). To reduce the likelihood that we had sequenced a pseudogene in any of the C. callipygus samples, we inspected the reading frames and found no premature stop codons. All substitutions were synonymous, thus not resulting in amino acid replacement.

\section{Congeneric species differences}

Based on the results of previous phylogenetic (Eaton et al. 2009) and morphological (Brochu 2007) studies, we treated African dwarf crocodiles (genus Osteolaemus) from Congo and Gabon as distinct species. We also considered the spectacled caiman (Caiman crocodilus chiapasius) and Yacare caiman (C. yacare) to be distinct taxa (Busack and Pandya 2001; Vasconcelos et al. 2006) and allowed for the possibility that our Nile crocodile (Crocodylus niloticus) samples represent distinct geographic lineages, based on the recent studies noted above.

The number of potentially diagnostic nucleotide characters between congeneric species ranged from 87 sites (13.5\% of the sequenced fragment length) between mustached (Cercopithecus cephus) and crowned (C. pogonias) guenons, to only four characters $(0.6 \%$ of the COX1 fragment) between Caiman yacare and Caiman crocodilus chiapasius (Table 4). Nucleotide divergence values for these species pairs were 0.164 and 0.013 , respectively (Table 5). C. yacare showed some evidence of paraphyly with C. c. chiapasius (bootstrap support $=87 \%$ ), based on one $C$. yacare sample (C. yacare7), while the C. c. chiapasius samples themselves grouped more strongly (96\%; Fig. 1a).

The average number of diagnostic sites for the 17 congeneric species pairs was 52.3 (8.1\% of fragment length; $\mathrm{SD}=18.4$ sites), corresponding to an average genetic divergence of $0.098(\mathrm{SD}=0.036)$. Position and character states of fixed nucleotide sites are presented in Table 4.
Among the three orders compared, average congeneric nucleotide divergence was smallest in the crocodilians $(0.065, \quad \mathrm{SD}=0.03 ; \quad$ excluding monotypic genera Melanosuchus and Mecistops) and highest among the three cercopithecoid primate species $(0.144, \quad \mathrm{SD}=0.029$; excluding monotypic Lophocebus). Average pairwise divergence among the five duiker species (0.104, $\mathrm{SD}=0.02$ ) was intermediate between primates and crocodilians. Figure 2 demonstrates the range of intraspecific nucleotide diversity found in this study as compared to sequence divergence between congeneric species pairs.

\section{Higher-order comparisons}

Comparing sequences between genera revealed average divergence values ranging from 0.084 (Caiman-Melanosuchus) to 0.212 (Cercopithecus-Lophocebus) within families, to a high of 0.295 between Suidae (Potamochoerus) and Bovidae (Cephalophus; Table 6). The greatest divergence between Alligatoridae and Crocodylidae was Paleosuchus to Osteolaemus (0.244; Table 6).

\section{Diagnosis of unknown samples}

We determined the species identity of the unknown crocodilian and ungulate samples by matching ostensibly fixed character sites and by placement and likelihood support in the phylogenetic trees. The sequence for the unknown caiman (Caiman1) matched the most common haplotype of Caiman latirostris and fell within this monophyletic group with 100\% node support (Fig. 1a). The museum sample identified as a hybrid caiman $(C$. c . crocodilus $\times$ yacare $)$ grouped with $C$. . . chiapasius + C. yacare7, but with low bootstrap support (34\%; Fig. 1a, node value not shown). This sample, however, matched with $C$. yacare at all diagnostic sites distinguishing the two species (Table 4). The crocodile skin handbag (1USFWS) matched closely (99.8\% identity) with the one Nile crocodile sampled in the Congo. Differentiation of these two samples from Nile crocodiles collected in Gabon received high bootstrap support (99\%, Fig. 1c). Comparing these putative groupings revealed 31 potentially fixed character differences and a sequence divergence of 0.053 between Nile crocodile clades (Table 4, 5). One unidentified ungulate sample (Uniden2) matched the most common Cephalophus monticola haplotype, while the remaining three (Uniden10, 11, 15) matched the most common $C$. callipygus haplotype. Phylogenetic placement of all four unknown ungulate samples was unambiguous (Fig. 1b). No unknown or misidentified primate samples were detected and therefore the phylogeny is not shown. 
Table 4 Nucleotide positions and character states of diagnostic sites in a 645 bp COX1 gene fragment. Twenty-one species from five tropical vertebrate mammals and reptiles are represented (see Table 1 for details on taxa and sample numbers and localities). Ambiguity codes denote that this position for a given species is not fixed and that the homologous position for another taxon is diagnostic

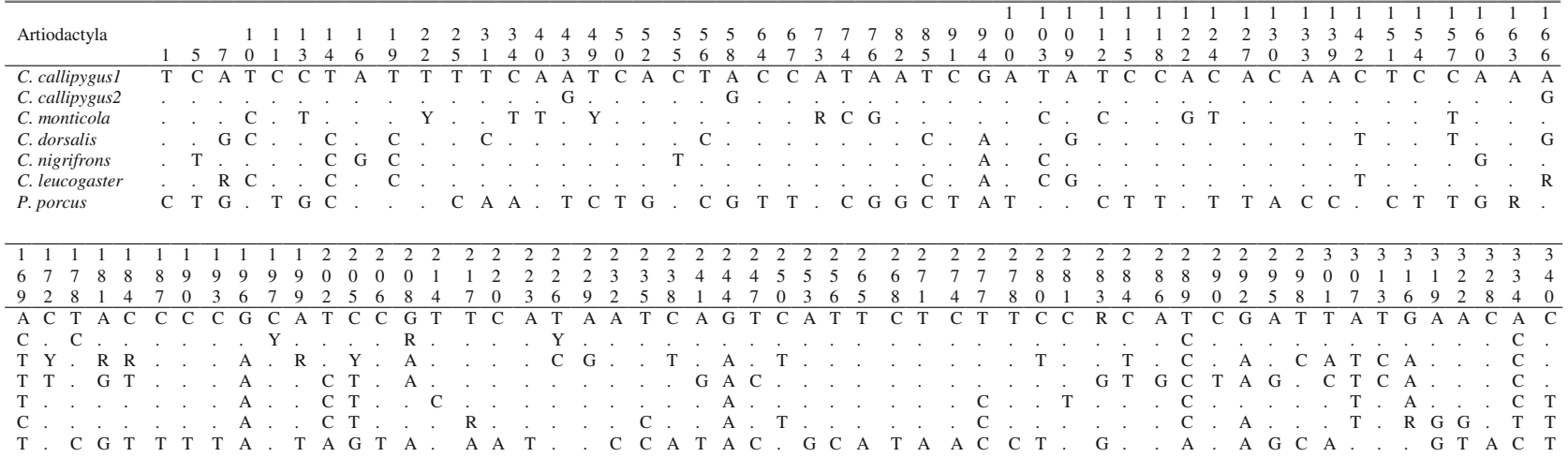

\begin{tabular}{lllllllllllllllllllllllllllllllllllllllllllllllllllllllllllllllllllll}
\hline 3 & 3 & 3 & 3 & 3 & 3 & 3 & 3 & 3 & 3 & 3 & 3 & 3 & 3 & 3 & 3 & 3 & 3 & 4 & 4 & 4 & 4 & 4 & 4 & 4 & 4 & 4 & 4 & 4 & 4 & 4 & 4 & 4 & 4 & 4 & 4 & 4 & 4 & 4 & 4 & 4 & 4 & 4 & 4 & 4 & 4 & 4 & 5 & 5 & 5 & 5 & 5 & 5 & 5 & 5 & 5 &
\end{tabular} \begin{tabular}{lllllllllllllllllllllllllllllllllllllllllllllllllllllllllll}
4 & 4 & 4 & 5 & 5 & 5 & 5 & 6 & 6 & 6 & 7 & 7 & 8 & 8 & 8 & 8 & 9 & 9 & 0 & 0 & 0 & 0 & 0 & 1 & 1 & 1 & 2 & 2 & 2 & 2 & 3 & 3 & 3 & 4 & 4 & 5 & 5 & 6 & 6 & 6 & 6 & 8 & 8 & 8 & 9 & 9 & 9 & 0 & 0 & 0 & 0 & 1 & 1 & 1 & 2 & 2 \\
3 & 6 & 7 & 2 & 5 & 8 & 9 & 1 & 4 & 7 & 3 & 6 & 2 & 5 & 6 & 8 & 1 & 4 & 0 & 1 & 3 & 6 & 9 & 2 & 5 & 8 & 1 & 4 & 7 & 8 & 3 & 6 & 9 & 5 & 8 & 1 & 7 & 0 & 3 & 6 & 9 & 1 & 4 & 7 & 0 & 3 & 6 & 0 & 2 & 5 & 8 & 1 & 7 & 8 & 3 & 6 & \\
\hline
\end{tabular}

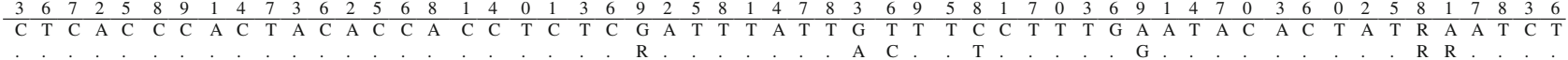

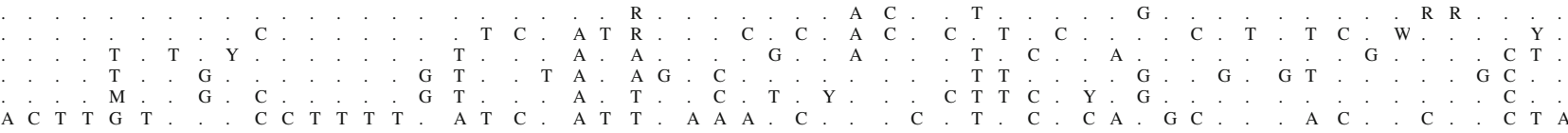

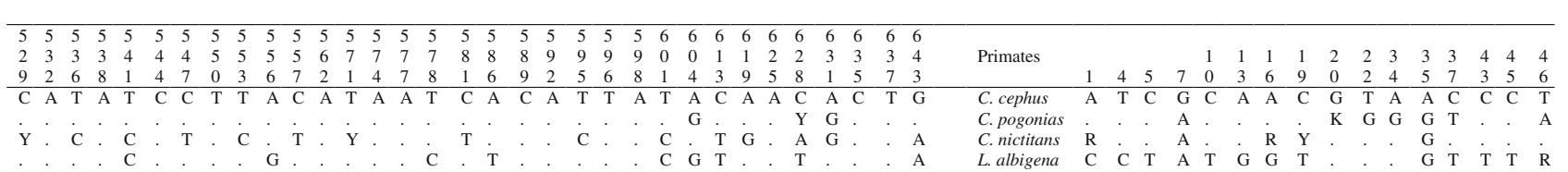

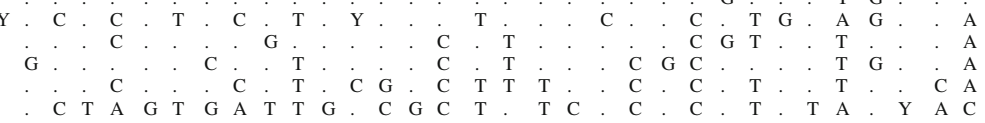

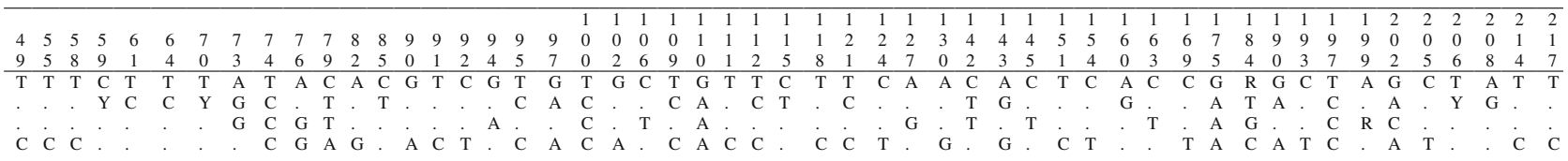
$\begin{array}{lllllllllllllllllllllllllllllllllllllllllllllllllllllllllllllllllllll}2 & 2 & 2 & 2 & 2 & 2 & 2 & 2 & 2 & 2 & 2 & 2 & 2 & 2 & 2 & 2 & 2 & 2 & 2 & 2 & 2 & 3 & 3 & 3 & 3 & 3 & 3 & 3 & 3 & 3 & 3 & 3 & 3 & 3 & 3 & 3 & 3 & 3 & 3 & 3 & 3 & 3 & 3 & 3 & 3 & 4 & 4 & 4 & 4 & 4 & 4 & 4 & 4 & 4\end{array}$

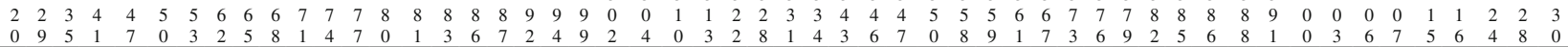

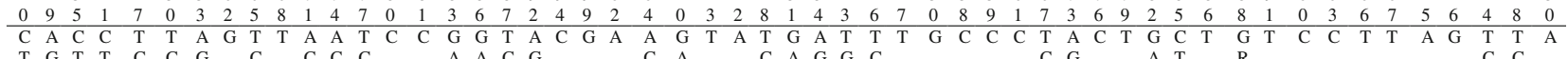

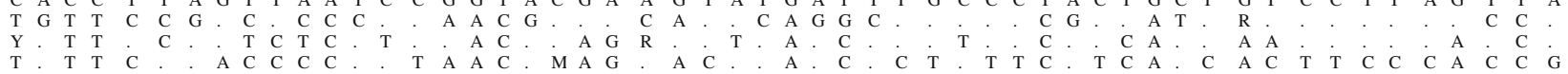

\begin{tabular}{llllllllllllllllllllllllllllllllllllllllllllllllllllll}
\hline 4 & 4 & 4 & 4 & 4 & 4 & 4 & 4 & 4 & 4 & 4 & 4 & 4 & 4 & 4 & 4 & 5 & 5 & 5 & 5 & 5 & 5 & 5 & 5 & 5 & 5 & 5 & 5 & 5 & 5 & 5 & 5 & 5 & 5 & 5 & 5 & 5 & 5 & 5 & 5 & 5 & 5 & 5 & 6 & 6 & 6 & 6 & 6 & 6 & 6 & 6 & 6 & 6
\end{tabular} $\begin{array}{llllllllllllllllllllllllllllllllllllllllllllllllllllllllllllllllllllllllllll}3 & 3 & 4 & 4 & 4 & 5 & 6 & 6 & 6 & 7 & 7 & 7 & 8 & 9 & 9 & 9 & 0 & 0 & 0 & 0 & 1 & 1 & 1 & 2 & 2 & 2 & 3 & 3 & 3 & 4 & 4 & 4 & 5 & 5 & 5 & 6 & 6 & 6 & 7 & 7 & 7 & 8 & 9 & 0 & 0 & 0 & 2 & 2 & 2 & 2 & 3 & 3 & 3\end{array}$ \begin{tabular}{llllllllllllllllllllllllllllllllllllllllllllllllllllll}
3 & 6 & 2 & 5 & 8 & 4 & 0 & 3 & 6 & 2 & 5 & 8 & 7 & 0 & 3 & 6 & 0 & 2 & 5 & 8 & 4 & 5 & 8 & 3 & 6 & 9 & 2 & 5 & 8 & 1 & 7 & 8 & 6 & 7 & 9 & 2 & 5 & 8 & 1 & 4 & 7 & 9 & 2 & 1 & 4 & 7 & 0 & 1 & 2 & 8 & 1 & 4 & 7 \\
\hline
\end{tabular}

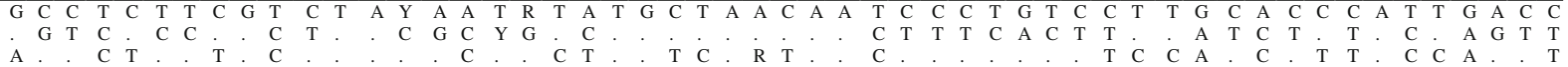

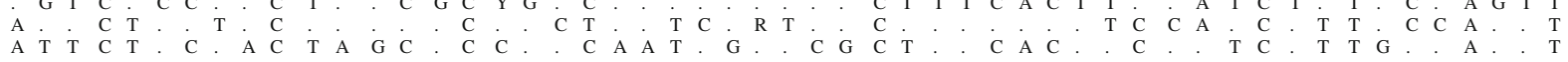
\begin{tabular}{llllllllllllllllllllllllllllllllllllllllllllllllllllllllllll}
\hline & & & 1 & 1 & 1 & 1 & 1 & 1 & 1 & 1 & 1 & 1 & 1 & 1 & 1 & 1 & 1 & 1 & 1 & 1 & 2 & 2 & 2 & 2 & 2 & 2 & 2 \\
Crocodylidae & 1 & 1 & 2 & 2 & 3 & 3 & 3 & 4 & 4 & 5 & 5 & 5 & 5 & 6 & 6 & 7 & 7 & 8 & 8 & 8 & 9 & 9 & 9 & 0 & 0 & 0 & 1 & 2 & 2 & 2 & 4 & 5 & 5 & 6 & 6 & 7 & 7 & 7 & 9 & 9 & 9 & 0 & 0 & 1 & 1 & 1 & 2 & 2
\end{tabular}

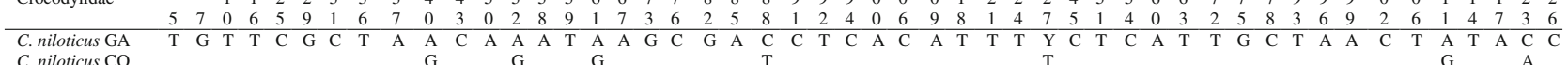

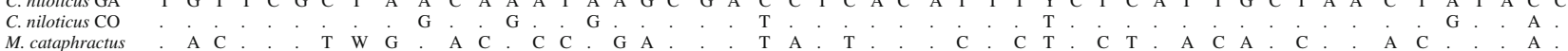

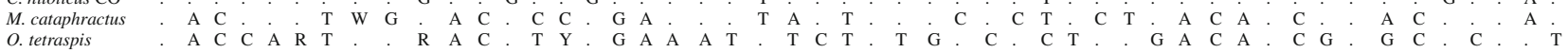

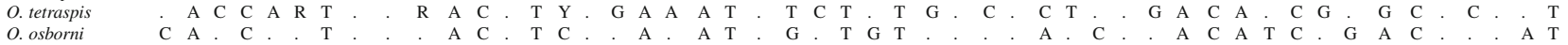

\begin{tabular}{llllllllllllllllllllllllllllllllllllllllllllllllllllllllllllllllllll}
\hline 2 & 2 & 2 & 2 & 2 & 2 & 2 & 2 & 2 & 2 & 2 & 2 & 2 & 2 & 2 & 2 & 2 & 2 & 2 & 3 & 3 & 3 & 3 & 3 & 3 & 3 & 3 & 3 & 3 & 3 & 3 & 3 & 3 & 3 & 3 & 3 & 3 & 3 & 3 & 3 & 3 & 3 & 4 & 4 & 4 & 4 & 4 & 4 & 4 & 4 & 4 & 4 & 4 & 4 & 4 & 4
\end{tabular}

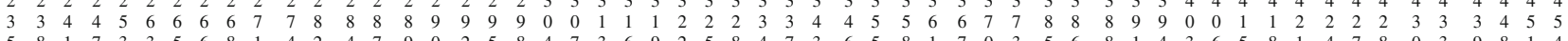

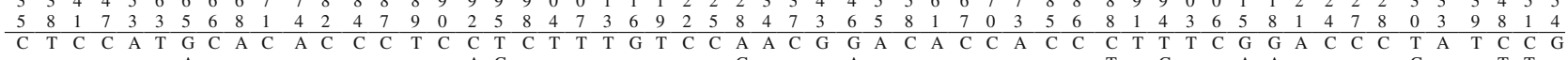

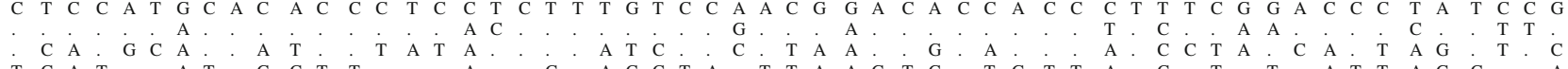

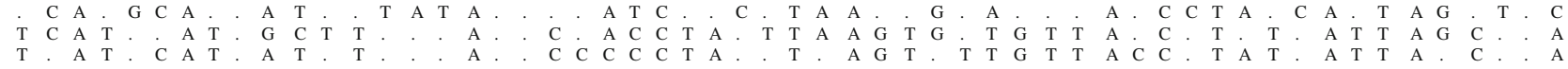


Table 4 continued

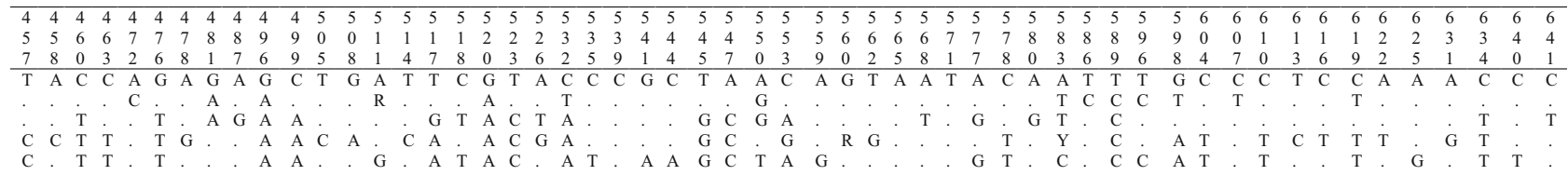

\begin{tabular}{|c|c|c|c|c|c|c|c|c|c|c|c|c|c|c|c|c|c|c|c|c|c|c|c|c|c|c|c|c|c|c|c|c|c|c|c|c|c|c|c|c|c|c|c|c|c|c|c|c|c|c|c|}
\hline \multirow{3}{*}{ Alligatoridae } & & & & & & & & & & & & & & & & & & & & & & & & & & & & & & & & & & & & & & & & & & & & 22 & 22 & & 2 & 2 & 2 & 2 & \\
\hline & & 1 & 2 & 2 & 2 & 2 & 2 & 3 & 4 & 4 & 4 & 5 & 5 & 5 & 8 & 8 & 9 & 9 & 0 & 0 & 1 & 1 & 2 & 22 & 2 & & 3 & 4 & 4 & 4 & 4 & 5 & 6 & 7 & 8 & 8 & 0 & 0 & 0 & 0 & 1 & 2 & 3 & 46 & 6 & 6 & 6 & 8 & & 90 & 0 \\
\hline & 7 & 3 & 2 & 3 & 5 & 8 & 9 & 1 & 1 & 3 & 9 & 1 & 2 & 8 & 2 & 5 & 1 & 4 & 0 & 6 & 2 & 8 & 4 & & 0 & & 6 & 2 & & 3 & 5 & 4 & 6 & 0 & 1 & 7 & 2 & 5 & 6 & 87 & 7 & & 8 & 73 & 3 & 5 & & 6 & & $8 \quad 1$ & \\
\hline C. yacare & $\mathrm{C}$ & $\mathrm{T}$ & $\mathrm{A}$ & $\mathrm{A}$ & $\mathrm{C}$ & $\bar{R}$ & G & $\mathrm{C}$ & $\mathrm{G}$ & $\mathrm{A}$ & $\mathrm{A}$ & $\mathrm{T}$ & $\mathrm{T}$ & $\mathrm{C}$ & $\mathrm{G}$ & $\mathrm{C}$ & $\mathrm{C}$ & $\bar{C}$ & $\mathrm{~A}$ & $\mathrm{C}$ & $\mathrm{C}$ & 5 & 51 & T T & T C & $\overline{\mathrm{C} \quad \mathrm{C}}$ & $\bar{C}$ & $\mathrm{C} \mathrm{C}$ & $\bar{c}$ & $\mathrm{~A}$ & $\mathrm{~T}$ & $\mathrm{~T}$ & A & $\mathrm{G}$ & $\mathrm{C}$ & $\mathrm{T}$ & $\mathrm{C}$ & $\mathrm{C}$ & $T$ & A. & $\mathrm{A}$ & $\mathrm{G}$ & $\mathrm{A}$ & $\mathrm{C}$ & $\mathrm{C}$ & $T A$ & A $T$ & $\begin{array}{ll}\mathrm{T} & \mathrm{A} \\
\end{array}$ & & C $\mathrm{T}$ & T C \\
\hline C. latirostris & & & & & $\mathrm{T}$ & A & & & $\mathrm{R}$ & . & C & W & . & & & & & & G & & . & & & . & C. & & $\mathrm{T}$ & $\mathrm{T} \quad \mathrm{T}$ & $\Gamma$ & & & C & & A & Y & & $\mathrm{T}$ & & & & G & . & C & $\mathrm{T}$ & $\mathrm{T}$ & A C & & C. & & . & \\
\hline C. c. chiapasius & & & & & & G & & & . & . & . & . & & & & & & & . & & . & & & & & & & $\mathrm{T}$ & & & & . & $\mathrm{R}$ & & . & & & . & & & & . & & & & & & . & & & \\
\hline M. niger & A & & G & & $\mathrm{T}$ & A & & & . & & & & C & & A & & $\mathrm{T}$ & A & & & & T & & & C. & & & $\mathrm{T}$ & $\Gamma$ & & $\mathrm{C}$ & & & A & & & $\mathrm{T}$ & A & & G & & & & & $\mathrm{T}$ & A & C & & A & & \\
\hline P. palpebrosus & G & $\mathrm{C}$ & G & G & & A & $\mathrm{K}$ & & & $\mathrm{C}$ & & & C & $\mathrm{T}$ & A & A & & A & $\mathrm{R}$ & $\mathrm{Y}$ & & T & $\Gamma$ & $\mathrm{C} C$ & C $\mathrm{T}$ & T. & & $\mathrm{T}$ & & & & & & & . & C & $\mathrm{R}$ & & & & $\mathrm{R}$ & A & G & & & A & C & $\mathrm{G}$ & C & $\mathrm{T}$ & C \\
\hline P. trigonatus & A & $\mathrm{C}$ & G & G & $\mathrm{T}$ & A & $\mathrm{T}$ & $\mathrm{T}$ & $\mathrm{K}$ & $\mathrm{C}$ & & . & C & & A & A & & A & & & $\mathrm{T}$ & $\Gamma$ & & & & & & & & G & & $\mathrm{C}$ & & & . & & & & $\mathrm{C}$ & & & A . & & . & & A & $\mathrm{C}$ & $\mathrm{C}$ & $\mathrm{C}$ & $\mathrm{T}$ & \\
\hline
\end{tabular}
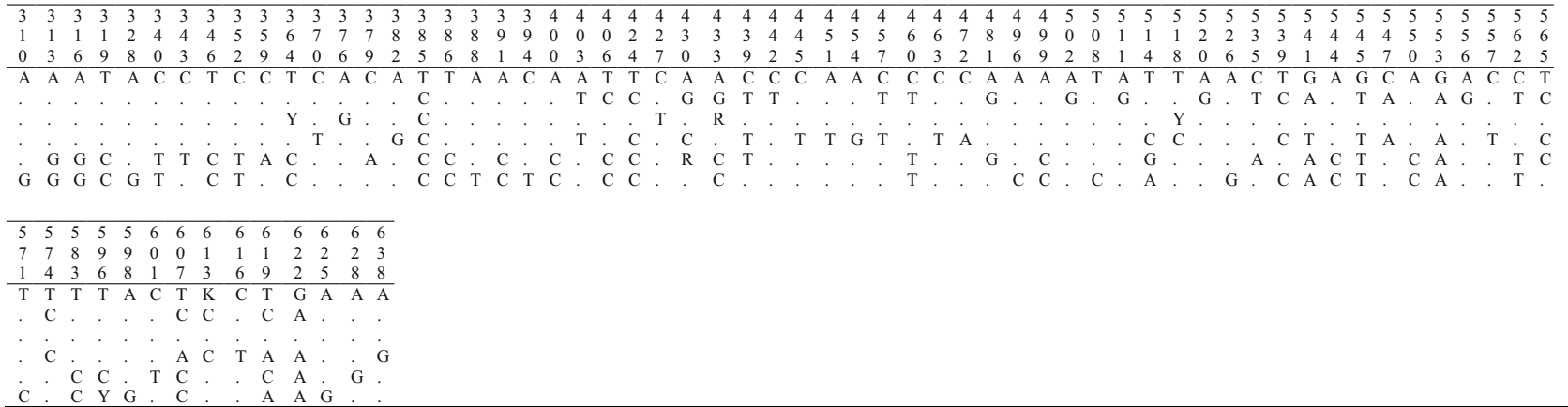

\section{Discussion}

Methodological considerations

Universal primer cocktails compiled by Ivanova et al. (2007; Table 3) successfully amplified the targeted barcode region for all eleven genera included in this study. High quality sequence data were generated from older specimens and those stored under suboptimal conditions, including dried tissue and blood maintained at room temperature for more than 20 years. DNA extraction and sequencing of confiscated crocodile leather products proved difficult, however, with only one of five skins identified. The tanning process used to preserve the crocodile leather, although apparently minimal, likely contributed to DNA degradation. Following additional optimization of PCR thermal profiles and reaction volumes, and re-extraction of difficult samples, we were ultimately unable to produce sequences from $12.3 \%$ of tissue samples. Tissue stored in buffered solution required the least procedural modifications for amplification and sequencing. Specimens stored as dried tissue or dried blood on gauze stored longer than 15 years were the most unreliable in producing high quality sequences. Problems associated with amplification of degraded DNA are well known (Deagle et al. 2006; Shapiro et al. 2004; Vuissoz et al. 2007) and it is unlikely that recovering full-length COX1 barcodes ( $\sim 650 \mathrm{bp})$ from processed animal products will be routinely successful. Hajibabaei et al. (2006) recognized this limitation and designed compatible primers to sequence short COXI barcode fragments (221 and $134 \mathrm{bp}$ ) in Lepidoptera and Hymenoptera. Appreciating the importance of a varied molecular toolkit, we are using the taxa included in the current study to develop and test a suite of mini-barcode primers to be paired with the existing universal $5^{\prime}$ primer set of Ivanova et al. (2007) to sequence fragments in the range of $150-350 \mathrm{bp}$. Initial trials on samples with low probabilities of producing full barcode sequences (leather products and museum specimens) are promising and appear to capture sufficient numbers of diagnostic characters for species identification (data not shown). The primer sets and our results will be reported in a subsequent publication.

Intraspecific variation

Intraspecific variation in the barcode region was low and generally fell within reported ranges of within-species mtDNA divergence (rarely exceeding $2 \%$, Avise 2000). In this study, we encountered two species with genetic distances approaching the expected upper range of intraspecific variation. We observed the greatest amount of nucleotide diversity $(1.92 \%)$ in the Nile crocodile (C. niloticus). This crocodilian is now considered to be two genetically distinct lineages based on multiple lines of evidence (Hekkala 2004; Schmitz et al. 2003). Although the previous studies did not include COXI, we sequenced the 
Table 5 Inter- and intraspecific nucleotide differences in the COX1 gene for three orders of tropical mammals and reptiles. The lower triangular matrix quantifies the number of fixed, diagnostic nucleotide positions between species pairs within each order; values in the upper matrix represent pairwise nucleotide divergence (Tamura-Nei) across the $645 \mathrm{bp}$ fragment of COX1. Diagonal values (in bold) are the average number of base substitutions per site $(\times 100)$ for intraspecific comparisons

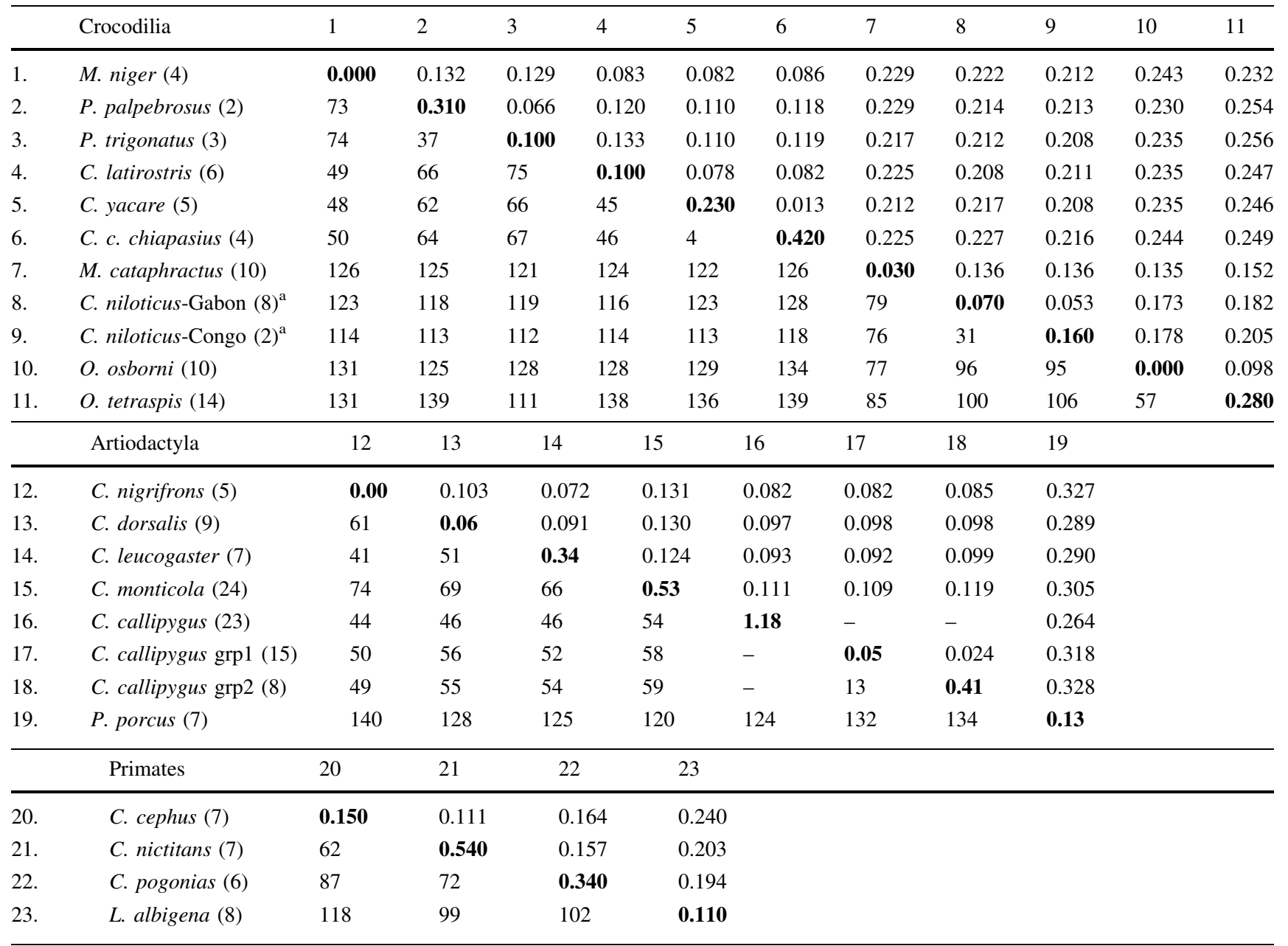

${ }^{a}$ Analyzed as a single species, intraspecific variability of $C$. niloticus was $1.92 \%$

12S rRNA gene for Nile crocodiles from Congo and Gabon (Eaton, unpublished data) to compare with the lineages described by Schmitz et al. (2003) and Hekkala (2004). We found that Gabon crocodiles grouped strongly (ML bootstrap support $=96 \%$ ) with the assemblage including South Africa, Madagascar, Kenya, Zimbabwe, Sudan and Egypt (GenBank accession numbers: AY195943, AY195945, AY195946, AY195950-AY195955). The Congo specimen and handbag aligned with samples from Senegal, Chad, the Gambia and Mauritania (AY195944, AY195947AY195949, AY195956, AY195957) with similar bootstrap support (96\%). Although it is not possible to compare Nile crocodile $C O X 1$ barcodes directly to clades produced by the $12 \mathrm{~S}$ rRNA gene, we infer that the differentiation of barcode samples from Congo and Gabon corroborate the earlier studies and represent a geographic division between the former conspecific crocodiles.
Peter's duiker (Cephalophus callipygus) was the second species with relatively high levels of intraspecific diversity. A subgroup of eight individuals displayed putative fixed characters at more than half of the variable sites for this species and formed a paraphyletic assemblage (Fig. 1b). Although NuMts (mitochondrial pseudogenes in the nucleus) are not easy to diagnose in cases of noncoding DNA (Kolokotronis et al. 2007), they often contain premature stop codons and frame-shift mutations (e.g. Chung and Steiper 2008; Lemos et al. 1999). Our sequence data contained neither, suggesting NuMts are unlikely to explain the observed sequence variation and phylogenetic pattern. In an extensive DNA barcode survey of birds, Kerr et al. (2007) were able to detect a low prevalence of pseudogenes due to their generally reduced size (100-200 bp) and, presumably, disrupted reading frames. Hybridization with another duiker species is also an unlikely explanation for 
Fig. 2 Frequency histogram of intraspecific $C O X 1$ sequence diversity ("species") compared to nucleotide divergence between pairs of congeneric sister species analyzed in this study. Only sister species Caiman yacare and $C$. crocodilus chiapasius had a divergence value overlapping the range of intraspecific nucleotide polymorphisms. The taxonomy of these two species is still being investigated

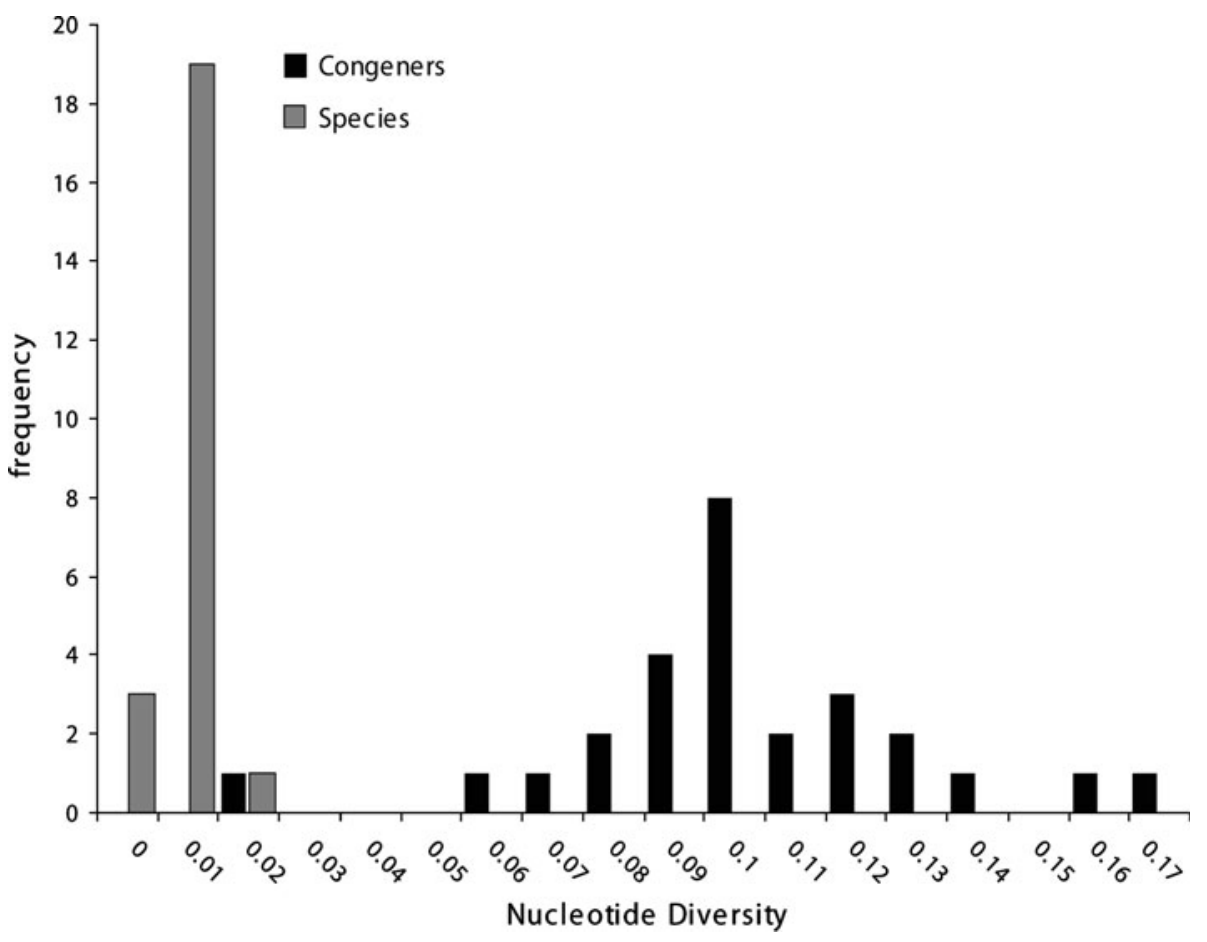

Table 6 Average nucleotide divergence (Tamura-Nei) between genera within orders for a $645 \mathrm{bp}$ fragment of COX1 mtDNA

\begin{tabular}{lll}
\hline Order (Family) & Genera compared & Divergence \\
\hline Artiodactyla & Cephalophus-Potamochoerus & 0.295 \\
Primates & Cercopithecus-Lophocebus & 0.212 \\
Crocodilia & Caiman-Crocodylus & 0.214 \\
& Caiman-Mecistops & 0.221 \\
& Caiman-Osteolaemus & 0.243 \\
& Melanosuchus-Crocodylus & 0.217 \\
& Melanosuchus-Mecistops & 0.229 \\
& Melanosuchus-Osteolaemus & 0.238 \\
& Paleosuchus-Crocodylus & 0.212 \\
& Paleosuchus-Mecistops & 0.223 \\
& Paleosuchus-Osteolaemus & 0.244 \\
(Alligatoridae) & Caiman-Melanosuchus & 0.084 \\
& Caiman-Paleosuchus & 0.118 \\
& Melanosuchus-Paleosuchus & 0.131 \\
(Crocodylidae) & Crocodylus-Osteolaeumus & 0.184 \\
& Crocodylus-Mecistops & 0.136 \\
& Osteolaemus-Mecistops & 0.143 \\
\hline
\end{tabular}

these findings, as our sample set included all sympatric duikers found in the Republic of Congo with the exception of the yellow-backed duiker ( $C$. silvicultor), a much larger species not likely to interbreed with $C$. callipygus. Our observation of cryptic genetic variation in Peter's duiker is corroborated by at least one other molecular study which found two major clusters of $C$. callipygus in forests of central Gabon, although the authors offered no discussion of this observation (van Vliet et al. 2008).

Because inference on divergence was based on a single mitochondrial locus within a sympatric population of C. callipygus, we cannot reject the possibility that our observations may conflict with the genome tree or true phylogeny for this species due to introgressive hybridization or incomplete lineage sorting (Funk and Omland 2003). Such concerns are reduced in the case of the Nile crocodile, for which analysis of additional genes (including nuclear loci) corroborate those of COXI in refuting an imperfect species taxonomy (Hekkala 2004; Schmitz et al. 2003). However, since our results are reported for allopatric populations of Nile crocodiles, introgression may in fact be an important consideration in future analyses if single-gene phylogenies are constructed from specimens sampled in putative hybrid zones.

\section{Interspecific variation}

While a character-based approach has been recommended as an improvement over distance-based thresholds for species identification (Rach et al. 2008; Rubinoff et al. 2006), the interspecific differences we present here are based on both distance metrics and diagnostic nucleotide characters. Mean congeneric nucleotide divergence in our study was $9.8 \%$ and the average number of fixed characters was 52.3. Variation between congeneric species pairs substantially exceeded levels of intraspecific polymorphism and fell within the range of genetic divergences 
reported for a wide range of vertebrate taxa. Hebert et al. (2003b) found that $93.8 \%$ of vertebrate congeners had a sequence divergence between 4 and $32 \%($ mean $=9.6 \%)$ for the same region of COXI while Johns and Avise (1998) reported average genetic distances for congeneric mammal and reptile species generally exceeded $\sim 3 \%$ in the mitochondrial cytochrome $b$ gene. One exception observed here was between Caiman yacare and C. crocodilus chiapasius, whose taxonomy is still under debate, but for which a small number of diagnostic characters $(n=4)$ may reliably identify individuals to species (Table 4).

Identification of unknown and misidentified samples

The primary intent of this work was to evaluate whether COX1 barcoding would serve as a reliable means to identify wildlife species sampled during bushmeat monitoring or while investigating trade in embargoed wildlife products. Matching homologous diagnostic sites and phylogenetic methods unequivocally assigned all unknown samples to the correct species, including caiman, crocodiles and ungulates. Barcode sequences also identified errors in identification or labeling that occurred during field collection or in museum accessioning.

\section{Conclusions}

Our results suggest that with minimal effort and simple refinements to DNA extraction and PCR protocols, accurate barcode sequence data can be obtained from most wildlife products encountered in bushmeat monitoring programs and wildlife investigations. Sequencing shorter barcode fragments should increase the success of working with degraded DNA samples and we have begun work to modify universal primers that will contribute to this effort for a wide range of taxa. Strong phylogenetic support and the high frequency of fixed character states between closely related taxa offer convincing evidence that $C O X 1$ barcoding gene will reliably diagnose many common African and neotropical bushmeat species. Bushmeat monitoring and investigations of wildlife commercialization and trade are likely to benefit from this molecular approach, especially when sampling from semi-processed products (e.g. from urban or import markets), when working with products that are difficult to identify (e.g. bird and reptile eggs, fish species, skins), or when focusing in areas containing morphologically cryptic species. In an effort to reduce inevitable errors while conducting field research and in museum curation, mtDNA barcoding offers a simple, low-cost and accurate method for verifying species identities. Although additional independent lines of evidence are needed to substantiate the levels of divergence observed in Peter's duiker (C. callipygus), barcodes may have highlighted a novel evolutionary lineage worthy of further investigation. Finally, generating a database of barcode sequences for tropical wildlife will offer researchers, conservationists and managers an effective tool for more precisely delineating the extent, range and genetic diversity of species of concern.

Acknowledgments This work was supported by the Alfred P. Sloan Foundation and the Richard Lounsbery Foundation. The National Science Foundation and the American Museum of Natural History's Research Experience for Undergraduates Program supported the laboratory work of GLM. The AMNH sponsored Aritra Datta and Arlene Amador to extract and sequence the USFWS crocodile skin products and we thank them for their efforts. Field support was provided to MJE by the Wildlife Conservation Society's Congo and Gabon programs, the National Geographic Society, the Rufford Foundation, Lincoln Park Zoo's Asia \& Africa Fund and the MacArthur Program of the University of Minnesota. MJE thanks Paul and Sarah Elkan (WCS-Congo), Debora Pires, and Congo field assistants Yamba Flavien, Bienvenu Kimbembe and Rufin Lekana. New World crocodilian samples were collected by Peter Brazaitis, Carlos Yamashita (IBAMA, Brazil) and George Rebelo (INPA, Brazil) and provided by G. J. Watkins-Colwell of the Peabody Museum. Ellen Bean and three anonymous reviewers greatly improved the clarity and scope of this manuscript.

\section{References}

Albrechtsen L, David WMA, Paul JJ et al (2007) Faunal loss from bushmeat hunting: empirical evidence and policy implications in Bioko island. Environ Sci Policy 10:654-667

Avise JC (2000) Phylogeography: the history and formation of species. Harvard University Press, Cambridge

Baker CS (2008) A truer measure of the market: the molecular ecology of fisheries and wildlife trade. Mol Ecol 17:3985-3998

Baker CS, Cipriano F, Palumbi SR (1996) Molecular genetic identification of whale and dolphin products from commercial markets in Korea and Japan. Mol Ecol 5:671-685

Baker CS, Dalebout ML, Lento GM et al (2002) Gray whale products sold in commercial markets along the pacific coast of Japan. Mar Mamm Sci 18:295-300

Bennett EL, Blencowe E, Brandon K et al (2007) Hunting for consensus: reconciling bushmeat harvest, conservation, and development policy in west and central Africa. Conserv Biol $21: 884-887$

Bickford D, Lohman DJ, Sodhi NS et al (2007) Cryptic species as a window on diversity and conservation. Trends Ecol Evol 22:148-155

Birstein VJ, Doukakis P, Sorkin B et al (1998) Population aggregation analysis of three caviar-producing species of sturgeons and implications for the species identification of black caviar. Conserv Biol 12:766-775

Brochu CA (2007) Morphology, relationships, and biogeographical significance of an extinct horned crocodile (Crocodylia, Crocodylidae) from the Quaternary of Madagascar. Zool J Linn Soc 150:835-863

Brower AVZ (1999) Delimitation of phylogenetic species with DNA sequences: a critique of Davis and Nixon's population aggregation analysis. Syst Biol 48:199-213

Busack SD, Pandya S (2001) Geographic variation in Caiman crocodilus and Caiman yacare (Crocodylia: Alligatoridae): systematic and legal implications. Herpetologica 57:294-312 
Chomel BB, Belotto A, Meslin FX (2007) Wildlife, exotic pets, and emerging zoonoses. Emerg Infect Dis 13:6-11

Chung W, Steiper M (2008) Mitochondrial CO1I introgression into the nuclear genome of Gorilla gorilla. Int J Primatol 29:13411353

Davis JI, Nixon KC (1992) Populations, genetic variation, and the delimitation of phylogenetic species. Syst Biol 41:421-435

Deagle BE, Eveson JP, Jarman SN (2006) Quantification of damage in DNA recovered from highly degraded samples-a case study on DNA in faeces. Front Zool 3:11

DeSalle R (2006) Species discovery versus species identification in DNA barcoding efforts: response to Rubinoff. Conserv Biol 20:1545-1547

Eaton MJ (2002) Subsistence wildlife hunting in a multi-use forest of the Republic of Congo: monitoring and management for sustainable harvest (Unpublished MS thesis), University of Minnesota, St. Paul, p 90

Eaton MJ (2006) Ecology, conservation and management of the Central African dwarf crocodile (Osteolaemus tetraspis), a progress report pp 84-95. Crocodiles: Proceedings of the 18th working meeting of the IUCN-SSC Crocodile Specialist Group, IUCN, Gland, Switzerland

Eaton MJ, Barr B (2005) Regional Africa report: Lac Tele, Rep. of Congo. Crocodile Specialist Group Bull 24:18-20

Eaton MJ, Martin AP, Thorbjarnarson J et al (2009) Species-level diversification of African dwarf crocodiles (Genus Osteolae$m u s$ ): a geographic and phylogenetic perspective. Mol Phylogenet Evol 50:496-506

Estes RD (1991) The behavior guide to African mammals: including hoofed mammals, carnivores, primates. The University of California Press, Berkeley

Fitzhugh K (2006) DNA barcoding: an instance of technology-driven science? Bioscience 56:462-463

Folmer O, Black M, Hoeh W et al (1994) DNA primers for amplification of mitochondrial cytochrome $c$ oxidase subunit I from diverse metazoan invertebrates. Mol Mar Biol Biotechnol 3:294-299

Funk DJ, Omland KE (2003) Species-level paraphyly and polyphyly: frequency, causes, and consequences, with insights from animal mitochondrial DNA. Annu Rev Ecol Evol Syst 34:397-423

Hajibabaei M, Smith MA, Janzen DH et al (2006) A minimalist barcode can identify a specimen whose DNA is degraded. Mol Ecol Notes 6:959-964

Hebert PDN, Cywinska A, Ball SL et al (2003a) Biological identifications through DNA barcodes. Proc R Soc Lond B Biol Sci 270:313-321

Hebert PDN, Ratnasingham S, deWaard JR (2003b) Barcoding animal life: cytochrome c oxidase subunit 1 divergences among closely related species. Proc R Soc Lond B Biol Sci 270:S96-S99

Hebert PDN, Penton EH, Burns JM et al (2004) Ten species in one: DNA barcoding reveals cryptic species in the neotropical skipper butterfly Astraptes fulgerator. Proc Natl Acad Sci USA 101:14812-14817

Hekkala E (2004) Conservation genetics at the species boundary: case studies from African and Caribbean crocodiles (genus Crocodylus) (Unpublished Ph.D. thesis), Columbia University, New York, p 142

Ivanova NV, Zemlak TS, Hanner RH et al (2007) Universal primer cocktails for fish DNA barcoding. Mol Ecol Notes 7:544-548

Janzen DH, Hajibabaei M, Burns JM et al (2005) Wedding biodiversity inventory of a large and complex Lepidoptera fauna with DNA barcoding. Phil Trans R Soc Lond B 360:1835-1845

Johns GC, Avise JC (1998) A comparative summary of genetic distances in the vertebrates from the mitochondrial cytochrome $b$ gene. Mol Biol Evol 15:1481-1490
Kaila L, Stahls G (2006) DNA barcodes: Evaluating the potential of COX1 to diffentiate closely related species of Elachista (Lepidoptera: Gelechioidea: Elachistidae) from Australia. Zootaxa 1170:1-26

Kerr KCR, Stoeckle MY, Dove CJ et al (2007) Comprehensive DNA barcode coverage of North American birds. Mol Ecol Notes $7: 535-543$

Kingdon J (1997) The Kingdon field guide to African mammals. Academic Press, London

Kolokotronis SO, MacPhee RDE, Greenwood AD (2007) Detection of mitochondrial insertions in the nucleus (NuMts) of Pleistocene and modern muskoxen. BMC Evol Biol 7:67

Lanave C, Preparata G, Saccone C et al (1984) A new method for calculating evolutionary substitution rates. J Mol Evol 20: $86-93$

Lemos B, Canavez F, Moreira M (1999) Mitochondrial DNA-like sequences in the nuclear genome of the opossum genus Didelphis (Marsupialia : Didelphidae). J Hered 90:543-547

Marko PB, Lee SC, Rice AM et al (2004) Mislabeling of a depleted reef fish. Nature 430:309-310

Martin AP (1991) Application of mitochondrial DNA sequence analysis to the problem of species identification of sharks. NOAA NMFS 115:53-59

McAliley LR, Willis RE, Ray DA et al (2006) Are crocodiles really monophyletic? Evidence for subdivisions from sequence and morphological data. Mol Phylogenet Evol 39:16-32

Milius S (2005) Bushmeat on the Menu: untangling the influences of hunger, wealth, and international commerce. Science News 167:138

Milner-Gulland EJ, Bennett EL, The SCB 2002 Annual Meeting Wild Meat Group (2003) Wild meat: the bigger picture. Trends Ecol Evol 18:351-357

Moura T, Silva MC, Figueiredo I et al (2008) Molecular barcoding of north-east Atlantic deep-water sharks: species identification and application to fisheries management and conservation. Mar Freshwater Res 59:214-223

Neigel J, Domingo A, Stake J (2007) DNA barcoding as a tool for coral reef conservation. Coral Reefs 26:487-499

Nowak RM (1999) Walker's mammals of the world. John Hopkins University Press, Baltimore

Rach J, DeSalle R, Sarkar IN et al (2008) Character-based DNA barcoding allows discrimination of genera, species and populations in Odonata. Proc R Soc Lond B Biol Sci 275:237-247

Ratnasingham S, Hebert PDN (2007) BOLD: The barcode of life data system. Mol Ecol Notes 7:355-364

Redford KH (1992) The empty forest. Bioscience 42:412-422

Rodriguez F, Oliver JL, Marin A et al (1990) The general stochastic model of nucleotide substitution. J Theor Biol 142:485-501

Ross HA, Lento GM, Dalebout ML et al (2003) DNA surveillance: web-based molecular identification of whales, dolphins, and porpoises. J Hered 94:111-114

Rubinoff D (2006) Utility of mitochondrial DNA barcodes in species conservation. Conserv Biol 20:1026-1033

Rubinoff D, Cameron S, Will K (2006) A genomic perspective on the shortcomings of mitochondrial DNA for "barcoding" identification. J Hered 97:581-594

Schmitz A, Mansfeld P, Hekkala E et al (2003) Molecular evidence for species level divergence in African Nile Crocodiles Crocodylus niloticus (Laurenti, 1786). CR Palevol 2:703-712

Shapiro B, Drummond A, Rambaut A et al (2004) Rise and fall of the Beringian steppe bison. Science 306:1561-1565

Song H, Buhay JE, Whiting MF et al (2008) Many species in one: DNA barcoding overestimates the number of species when nuclear mitochondrial pseudogenes are coamplified. Proc Natl Acad Sci USA 105:13486-13491 
Stamatakis A (2006) RAxML-VI-HPC: maximum likelihood-based phylogenetic analyses with thousands of taxa and mixed models. Bioinformatics 22:2688-2690

Stamatakis A, Hoover P, Rougemont J (2008) A rapid bootstrap algorithm for the RAxML web servers. Syst Biol 57:758-771

Tamura K, Nei M (1993) Estimation of the number of nucleotide substitutions in the control region of mitochondrial DNA in humans and chimpanzees. Mol Biol Evol 10:512-526

Tamura K, Dudley J, Nei M et al (2007) MEGA4: Molecular evolutionary genetics analysis (MEGA) software version 4.0. Mol Biol Evol 24:1596-1599

Thompson J, Higgins D, Gibson T (1994) CLUSTAL W: improving the sensitivity of progressive multiple sequence alignment through sequence weighting, position-specific gap penalties and weight matrix choice. Nucleic Acids Res 22:4673-4680

Thorbjarnarson JB, Eaton MJ (2004) Preliminary examination of crocodile bushmeat issues in the Republic of Congo and Gabon, pp 236-247. Crocodiles: Proceedings of the 17th working meeting of the IUCN-SSC Crocodile Specialist Group, IUCN, Gland, Switzerland van Vliet N, Zundel S, Miquel C et al (2008) Distinguishing dung from blue, red and yellow-backed duikers through noninvasive genetic techniques. Afr J Ecol 46:411-417

Vasconcelos WR, Hrbek T, Da Silveira R et al (2006) Population genetic analysis of Caiman crocodilus (Linnaeus, 1758) from South America. Genet Mol Biol 29:220-230

Vuissoz A, Worobey M, Odegaard N et al (2007) The survival of PCR-amplifiable DNA in cow leather. J Archeol Sci 34: 823-829

Witt JDS, Threloff DL, Hebert PDN (2006) DNA barcoding reveals extraordinary cryptic diversity in an amphipod genus: implications for desert spring conservation. Mol Ecol 15:3073-3082

Yan P, Wu X-B, Shi Y et al (2005) Identification of Chinese alligators (Alligator sinensis) meat by diagnostic PCR of the mitochondrial cytochrome $b$ gene. Biol Conserv 121:45-51

Yang ZH (1994) Maximum likelihood phylogenetic estimation from DNA sequences with variable rates over sites: approximate methods. J Mol Evol 39:306-314 